Journal of Korean Clinical Health Science. http://www.kschs.or.kr

Vol. 2, No. 2, June 2014, pp. 133-147

DOI:http://dx.doi.org/10.15205/kschs.2014.2.2.133

\title{
종양응급 상황에서의 방사선치료의 역할
}

\author{
이준호 ${ }^{1}$, 백홍석 $^{1}$, 박상섭 $^{2}$, 박현숙 $^{3}$, 이석호 ${ }^{4 *}$ \\ ${ }^{1}$ 대전대학교 응급구조학과, ${ }^{2}$ 충청대학교 응급구조학과, ${ }^{3}$ 대전대학교 병원경영학과 \\ ${ }^{4 *}$ 가천대학교 길병원 방사선종양학과
}

\section{Role of Radiation Therapy in Oncologic Emergencies}

\author{
Jun-Ho Lee ${ }^{1}$, Hong-Seok Baek ${ }^{1}$, Sang-Sub Park ${ }^{2}$, Hyun-Suk Park ${ }^{3}$, Seok-Ho Lee ${ }^{4} *$ \\ ${ }^{1}$ Department of Emergency Medical Technology, Daejeon University \\ ${ }^{2}$ Department of Emergency Medical Technology, Chungcheong University \\ ${ }^{3}$ Department of Health Service Management, Daejeon University \\ ${ }^{4 *}$ Department of Radiation Oncology, Gachon University Gil Medical Center \\ (Received April 6, 2014: Revised April 12, 2014: Accepted April 20, 2014)
}

\begin{abstract}
Purpose. Radiation therapy for oncologic emergencies is an important modality in the management of cancer patients. The aim of the present study was to review the roles of RT in oncologic emergencies based on literature review.

Methods. The oncologic emergencies requiring rapid treatment include superior vena cava syndrome, spinal cord compression, brain metastasis, and bone metastasis. We reviewed the literatures on the pathophysiology, diagnosis, and treatment of oncologic emergencies.

Results. In this literature review, radiation therapy among treatment modalities for oncologic emergencies has been shown to be fast and very effective treatment modality for oncologic emergencies.

Conclusions. Based on this review, we conclude that the literature provides support for the role of radiation therapy in the situation of oncologic emergencies. As the number of cancer patients increase, the prevalence of oncologic emergencies will increase. In the future, the development of RT techniques will provide the improvement of not only patient's quality of life but also the survival.
\end{abstract}

Key Words: Emergency, Oncology, Palliation, Radiation therapy 


\section{1. 서론}

종양 응급상황(oncologic emergency)은 암환 자에서 환자의 생명과 삶의 질을 심각히 위협 하며 영구적 손상을 초래할 수 있어 이에 대한 빠른 치료가 필요한 긴급상황으로 정의된다 ${ }^{1)}$. 이러한 응급상황은 진단 당시부터 발견될 수 도 있으나 대부분 치료 중 질환이 많이 진행되 어 발생하는 것으로 알려져 있다 ${ }^{2)}$. 임상적으로 는 암환자에서 응급질환은 대사적, 신경학적, 심혈관적, 혈액학적 그리로 감염적인 문제로 인하여 환자의 생명뿐 아니라 삶의 질을 악화 시키는 것을 방지하기 위하여 즉각적 시술이 필요한 질환들을 말한다. 이러한 응급질환들에 대한 치료방법으로 수술, 항암약물치료, 방사 선치료, 그리고 내과적 약물치료 등이 있다. 진행된 암 환자에서 응급상황은 언제든지 발 생할 수 있는데 이 경우 완화목적의 방사선치 료가 다양한 치료방법들 중 매우 중요한 역할 을 담당하고 있다. 최근 방사선치료기법의 발 전으로 진행된 암환자의 종양응급 상황에서 증상완화 뿐 아니라 근치적 목적으로 방사선 치료가 시행되고 있다. 본 종설에서는 암환자 에서 응급상황 시 방사선치료의 역할에 대하 여 알아보고 최신 방사선치료 기법을 포함한 다양한 방사선치료 기법들에 대하여 살펴보고 자 하였다.

\section{2. 연구대상 및 방법}

본 연구는 종양응급질환들 중 방사선치료가 시행되는 대표적 질환들을 국내외 문헌 고찰 을 통하여 종양응급상황의 발생기전, 증상, 진 단 그리고 치료방법을 중심으로 살펴봄으로써 방사선치료의 역할을 알아보고자 하였다.

\section{1. 연구대상}

국내와 국외로 나누어 수행하였다. 암환자에 서 즉각적인 시술이 필요한 다양한 응급질환들 중 방사선치료의 적응증에 해당하는 경우는 심 혈관 및 신경학적 문제로 인한 경우가 대부분 으로 대표적 질환으로 상대정맥증후군(superior vena cava syndrome), 척수압박증후군(spinal cord compression syndrome), 뇌전이(brain metastasis) 그리고 골전이(bone metastasis)를 들 수 있다. 이들 각각의 질환에 대하여 해당 문헌리뷰를 진행하였고 배경(원인 및 증상), 진 단 그리고 치료 순서로 내용을 정리하여 기술 하였다. 문헌검색은 종양 환자 중 응급질환으 로 치료를 진행하였던 연구를 중심으로 국내 및 국외문헌검색을 통해 진행하였고 국내 데이 터베이스의 경우 KoreaMed 그리고 한국의학논 문데이터베이스(Kmbase), 국립암센터 자료를 중심으로 검색하였다. 국외 데이터베이스는 의 학분약에서 대표적 데이터베이스인 Pubmed, The Cochrane library로 검색을 진행하였다.

\section{2. 연구방법}

국내 및 국외 데이터검색에 사용한 검색어는 ‘종양(oncology), 응급(emergency), 방사선치료 (radiation therapy), 증상완화(palliation) 그리고 최 신방사선치료 기법(radiation therapy technique)' 으로 설정하였고 세부적으로 '상대정맥증후군, 척수압박증후군, 뇌전이 그리고 골전이'를 설정 하였다. 검색된 문헌들 중 종양응급상황에서 시 행된 치료들 가운데 방사선치료와 연관된 문헌 들의 핵심적 내용들을 중심으로 선택하였다. 최 종 선택된 문헌들은 응급질환 별로 배경(원인 및 증상), 진단 그리고 치료로 나누어 정리를 진행하 였고 고찰에서는 응급질환별 방사선치료와 연관 된 타 연구결과 및 방사선 치료기법에 대하여 기 술하였다. 


\section{3. 연구결과}

3.1. 상대정맥증후군 (superior vena cava syndrome)

\section{1 .1 배경}

상대정맥증후군은 상대정맥을 통한 혈류의 흐름이 외인성(extrinsic) 혹은 내인성(intrinsic) 으로 폐색이 초래됨으로써 일어나는 증상을 말한다. 상대정맥 증후군을 일으키는 가장 흔 한 질환은 악성종양으로서 대표적으로 비소세 포폐암(non-small cell lung cancer), 소세포암 (small cell lung cancer), 비호즈킨즈 림프종 (non-Hodgkin lymphoma), 흥선종(thymoma) 등 이 있다. 이러한 원인들 중 폐암과 비호즈킨 림프종이 모든 상대정맥증후군 발생 원인의
약 $85 \%$ 를 차지하고 있으며 소세포폐암 중 약 $10 \%$, 비소세포암 중 약 2 4\%, 그리고 비호즈 킨 림프종 중 약 2 4\%에서 상대정맥증후군이 발생하는 것으로 보고되고 있다 ${ }^{3-5)}$. 폐암 중 특 히 소세포암은 중앙기도를 통해 빠르게 자라 는 경향을 보여 상대정맥 증후군을 더 잘 일으 키며 방사선치료와 항암약물요법을 병용하여 치료를 시행하면 치료에 반응률이 높은 편이 다(Figure 1). 대개, 1 개월 이내의 발병을 보이 는 것이 특징으로 이전에 특별히 암 진단을 받 지 않았던 경우가 많다. 상대정맥의 폐쇄로 인 해 윗부분의 정맥흐름에 장애가 발생하면서 상체에 관련 증상이 나타나게 되는데, 대표적 인 증상으로 안면종창, 팔부종, 및 호흡곤란 등이 있고 특히 앞으로 숙일 때 증상이 심해지 는 경향을 보인다.
(A)

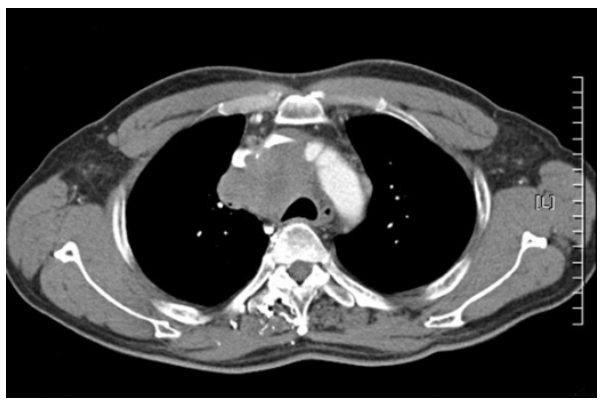

(B)

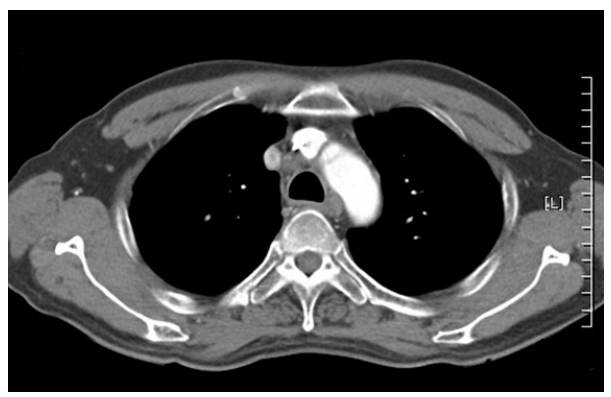

Figure 1. The 60-year-old male patient with severe dyspnea and facial swelling. (A) The chest computed tomography (chest $\mathrm{CT}$ ) showed about $6 \sim 7 \mathrm{~cm}$-sized mass compressing the superior vena cava. The biopsy of the mass revealed a small-cell carcinoma of the lung. The combination of radiation and chemotherapy was performed on this patient. One week after starting the treatment, the dyspnea and facial swelling was markedly relieved. (B) The chest CT at 4 months after the treatment showed a markedly reduced tumor mass.

\subsection{2 진단}

일차적으로 문진 및 진찰을 시행한다. 혈액 학적 검사 외에 단순흉부 방사선촬영(chest X-ray) 및 흥부전산단층촬영(chest CT)을 시행 하며 심한 호흡곤란 등 생명이 위태로울 경우 조직학적 확진 없이 치료를 시행하기도 하나
소세포암이나 림프종 등은 항암약물요법 혹은 방사선치료와의 병용요법으로 완치가 가능함 으로 가능한 조직검사를 시행하여야 한다 ${ }^{6}$. 흥부 방사선 사진 상 대부분 종물이 보이고 가 장 흔한 이상 소견은 종격상부 확장과 흉막유 출이며 병의 진행정도 등 은 흉부 단층촬영을 통해 자세히 알 수 있으며 특징적으로 측부혈 
류확장(collateral vessel dilatation) 소견을 보인 다. 상정맥증후군으로 방사선치료를 시행받기 전·후 단순흉부 방사선 및 흥부전산단층촬영
소견으로 치료에 대한 높은 반응률을 확인할 수 있다(Figure 2).
(A)
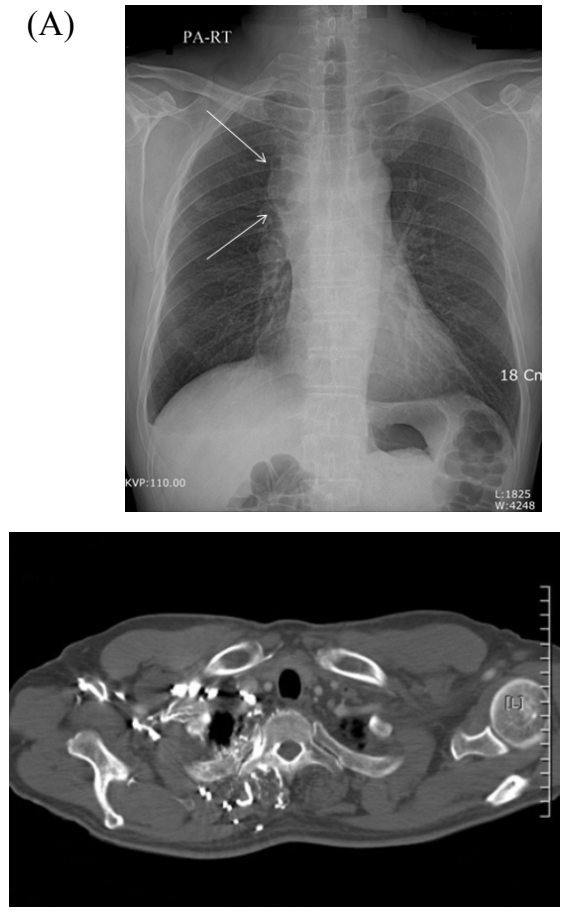

(B)
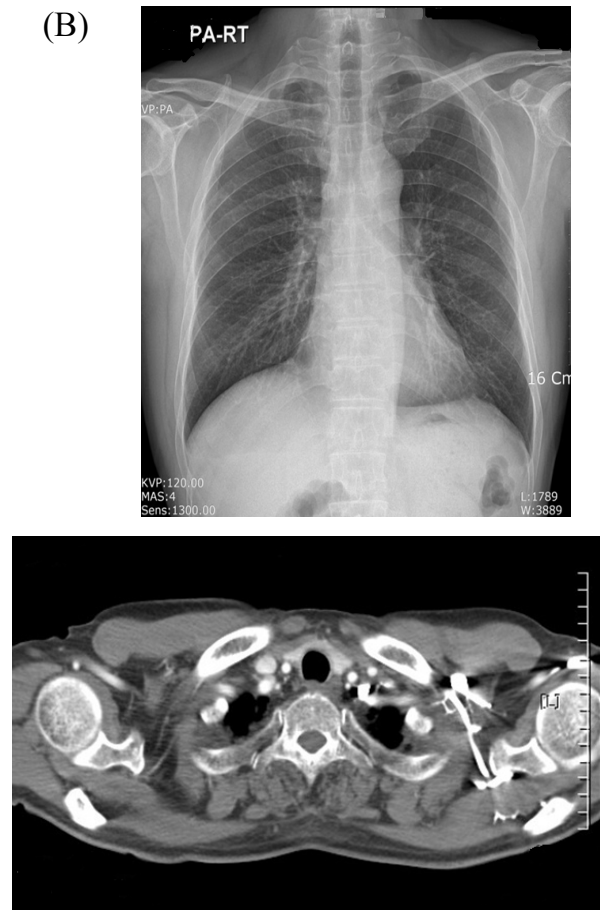

Figure 2. The patient with superior vena cava syndrome showed (A) a mediastinal widening on chest $\mathrm{X}$-ray and multiple venous collaterals in the right chest wall and paravertebral regions on chest CT. (B) The chest X-ray and CT findings at 4 months after the treatment showed a normalized shape and venous flow of the superior vena cava.

\subsection{3 치료}

진단명에 따른 원인 질환을 치료하는 것이 원칙이나 일차적으로 원인과 관계없이 스테로 이드를 투여하여 혈관벽의 부종을 경감시켜 환 자증상을 완화시켜야 한다 ${ }^{7-9)}$. 이후, 심한 호흡 곤란 등 응급상황으로 판단되었을 경우 방사선 치료를 시행할 수 있으나 우선적으로 조직검사 를 통한 병리학적 진단을 얻는 것이 원칙이다. 종양으로 인한 상대정맥증후군에 대한 치료방 법으로 방사선치료, 항암약물치료, 수술 그리고 스텐트시술 등이 있다. 방사선치료는 비소세포 폐암의 대표적 치료방법이며 항암약물요법이 우선적으로 시행되는 경우는 소세포폐암, 림프
종, 그리고 생식세포종양(germ cell tumor) 등이 있다. 항암약물요법이나 방사선치료에 반응하 지 않는 경우에는 수술적치료 등을 고려해야 한다. 상대정맥증후군은 응급방사선치료의 대 표적 질환 중 하나로 주 기관지가 막히거나, 후 두부종 등으로 인한 심한 호흡곤란 그리고 뇌 부종(cerebral edema)로 인한 이차적인 혼수 발 생이 의심되는 경우는 응급상황으로 스테로이 드 치료와 병행하여 응급방사선치료가 시작되 어야 한다. 방사선치료는 초기조기 증상완화를 위하여 소분할(hypofractionation) 조사방법을 시행하며 매일 3-4 Gy로 3-4회 치료를 시작한 다 $^{10,11)}$. 비소세포성폐암의 경우 소분할조사 이 후 통상분할 조사(conventional fractionation) 방 
법으로 변경하여 총 60-70 Gy 방사선을 약 6-7 주에 걸쳐 방사선치료를 진행하며 항암약물요 법을 병용하기도 한다. 림프종의 경우는 방사 선민감도(radiosensitivity)가 높아 총 35-45 Gy 의 방사선을 조사한다. 통상적으로 방사선치료 는 설계에서 치료시작까지의 시간이 적게 소요 되는 2차원방사선치료기 법(2-dimensional radiation therapy, 2D-RT)을 이용하여 시작하고 증상완화 이후에는 폐와 척수 등 정상조직을 보 호하기 위하여 3차원 입체조형기법(3-dimensional radiation therapy, 3D-CRT)으로 변경하 여 치료를 진행한다.

3.2. 척수압박증후군 (spinal cord compressionsyndrome)

\subsection{1. 배경}

척추로의 전이는 직접, 혈행성, 그리고 뇌척 수액을 통해서 발생하며 척추 전이 중 흥추전 이가 가장 흔하다. 암환자들 중 약5-10\%에서 척수압박을 보이는 것으로 알려지고 있다. 척 추 전이가 진행되어 척추압박을 일으키는 흔 한 질환으로 폐암, 유방암, 전립선암, 신장암, 그리고 림프종 등이 알려져 있다. 척수압박의 가장 흔한 증상은 허리통증으로 동시에 근통, 근력약화, 감각이상, 배변 및 배뇨이상 증상을 동반할 수 있고 심하면 마비증상을 보인다.

\subsection{2. 진단}

암환자에서 허리통증이 발생하였을 경우 척 추압박 유무 확인을 위한 신경학적 검진 및 척 추 자기공명영상 등 영상학적검사를 시행하여 야 한다. 척수압박으로 상하지 마비 발생 시 불가역적으로 진행되어 환자의 삶의 질을 현 격히 떨어뜨릴 수 있으므로 조기진단과 치료 가 매우 중요하다.

\subsection{3. 치료}

척수압박을 치료하는 방법으로는 스테로이 드, 수술, 그리고 방사선치료가 있다. 초기에 척수압박증후군이 의심되었을 경우, 문진과 더 불어 신경학적 검사를 시행하고 스테로이드 투여를 시작하며 동시에 방사선종양학과 및 신경외과의사에게 의뢰를 진행하고 치료방향 을 결정하여야 한다. 척수압박 진단 시 일반적 으로 스테로이드(dexamethasone) 용량 10 16 $\mathrm{mg}$ 을 정맥으로 정주(intravenous bolus)하며 이 후 $4 \mathrm{mg}$ 을 4 시간 간격으로투여하며 방사선치 료 등 치료 중 혹은 종결 후에 서서히 스테로 이드투여를 줄여야 한다 ${ }^{12-14)}$. 전통적으로 척추 후궁 절제술 (laminectomy)를 시행하게 되며 대개, 전방 감압술(anterior decompressive approach)을 사용한다. MRI상 단일병변이고 기대여명이 3 개월 이상인 경우 그리고 방사선 에 민감한 종양 (림프종, 생식세포종, 다발성골 수종 등)이 아닌 경우가 감압술의 좋은 적응증 에 해당한다 ${ }^{15)}$. 반면, 마비가 발생한지 48 시간 이상 지난 경우, 방사선에 민감한 종양, 이전 에 척추압박이 있었거나 다른 신경학적 질환 이 있는 경우는 비적응증에 해당한다. 척추 혹 은 척수전이로 인하여 척수압박증후군이 발생 한 경우로 수술적 적응증에 해당하지 않거나 마비가 발생한지 48 시간 이상 지나 병원에 내 원하여 수술적 적응에 해당하지 않는 경우, 즉 각적인 방사선치료가 시행하여야 한다 ${ }^{15)}$. 일반 적으로 응급방사선치료는 이차원방사선치료기 법을 이용하며 총 $30 \mathrm{~Gy}$ 방사선을 10 회에 나 누어 치료하는 것이 표준적 치료방법이다. 근 래에는 척추전이부위가 적거나 기대여명(life expectancy)이 양호한 경우 세기조절방사선치 료기법 등을 이용한 체부정위방사선치료기법 (stereotactic body radiation therapy, SBRT)을 적용하여 정상조직인 척수의 방사선량은 최소 
화하면서 종양부위에 가능한 많은 방사선량을 조사함으로써 국소제어율을 높일 수 있게 되 었다.

척수전이가 있었던 환자에 대하여 체부정위 방사선치료 기법을 이용하여 다양한 각도에서
여러 방사선빔을 사용하여 정상조직인 척수에 는 가능한 적은 방사선이 조사되도록 하면서 척추종양부위에는 많은 방사선이 정밀하게 조 사되도록 설계하였다(Figure 3).
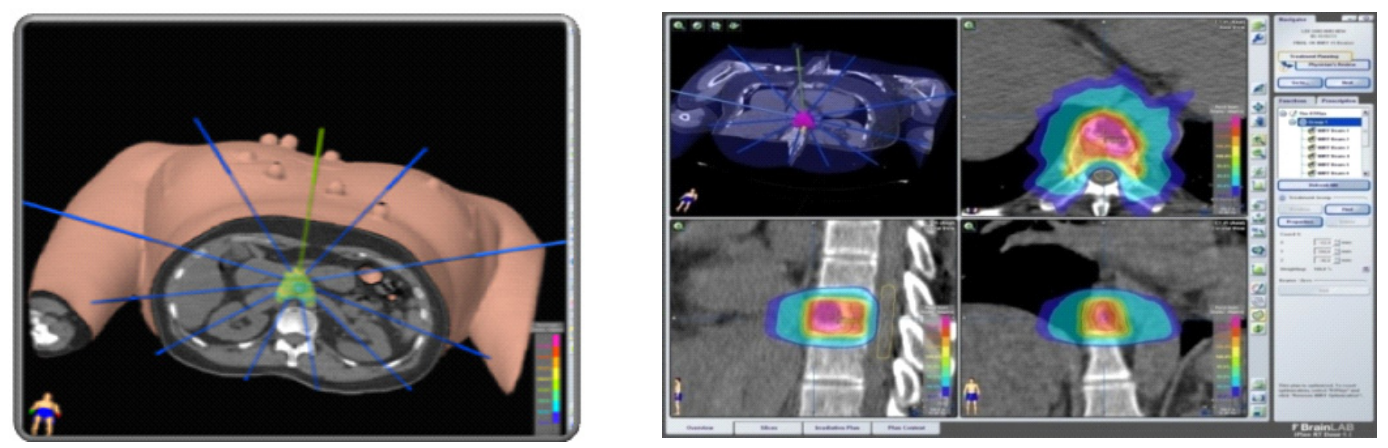

Figure 3. The patient with spine metastasis was treated with stereotactic body radiation therapy, by using multiple beams while avoiding the spinal cord, which can make treatment possible with less dose of radiation exposed to the normal tissue and more dose on the tumor as much as possible with the precise radiation dose distribution.

\section{3. 뇌전이(brain metastases)}

\subsection{1. 배경}

뇌에서 발생하는 악성종양 중 가장 흔한 종 양은 뇌전이암으로 모든 암환자의 약 10 30\% 에서 발생하는 것으로 알려져 있다. 이러한 뇌 전이암의 대표적 원발암으로 폐암, 유방암, 흑 색종, 대장암 그리고 신장암을 들 수 있다 ${ }^{16-18)}$. 대개, 뇌전이는 다발성으로 오며 주요 증상은 뇌압상승으로 인한 두통, 구역 및 구토증상으 로 뇌실질 내 위치에 따른 신경학적 증상, 의 식변화, 그리고 경련 등의 증상을 보인다. 발 생위치로 보면 천막상(supratentorial)에서 주로 발생하여 대뇌(cerebral hemisphere)가 약 $80 \%$ 를 차지하고 소뇌(cerebellum)가 약 $15 \%$ 그리고 뇌간(brain stem)이 약 $5 \%$ 를 차지하는 것으로 알려져 있다 ${ }^{19)}$. 뇌전이가 발생하는 중앙기간은 암진단 후 약 1 년 정도로 뇌전이 환자들 중 약 $30-50 \%$ 에서 뇌전이로 사망하는 것으로 알려져
있다.

\subsection{2. 진단}

뇌 전이가 의심되는 환자에서 병력청취 및 신경학적 진찰을 포함한 신체검진을 시행하며 신경학적 증상을 유발할 수 있는 감염성질환 여부를 위해 혈액학적 검사와 더불어 1차적으 로 뇌전이 여부를 확인하기 위하여 뇌 컴퓨터 단층촬영(brain $\mathrm{CT}$ ) 또는 뇌 자기공명영상촬영 (brain MRI)을 시행하여야 한다. 또한 암 진단 여부가 불확실한 경우 원발암 여부를 확인하 기 위한 추가검사가 시행되어야 한다.

\subsection{3. 치료}

뇌전이의 치료는 크게 단일 뇌전이가 있는 경우와 다발성 뇌전이가 있는 경우로 나누어 살펴볼 수 있다. 
1) 단일 뇌전이가 있는 경우(solitary brain metastasis)

단일 뇌전이면서 환자의 활동지수(Karnofsky performance status, KPS)가 좋고 뇌 이외 부위 가 잘 조절된 경우 수술적절제를 고려하여야 한다. 특히 암에 대한 병리학적 진단이 시행되 지 않았다면 우선적으로 수술을 시행하여야 한다. 수술적 절제 시행 후 전뇌방사선치료를 시행한 경우 수술적 절제 없이 전뇌방사선치
(A)

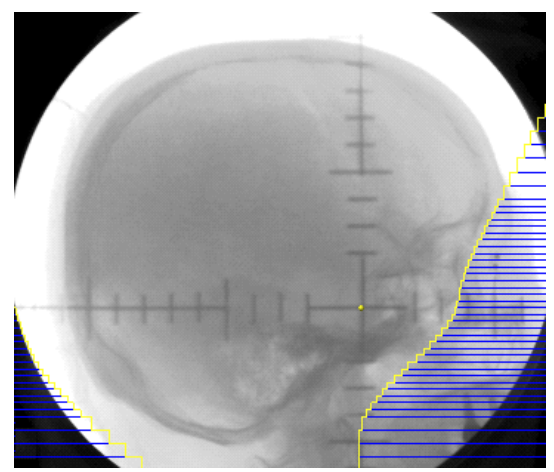

료만을 시행한 경우보다 생존율 향상 뿐 아니 라재발률을 낮추고 환자의 신경학적 증상호전 기간을 늘릴 수 있는 것으로 알려져 있다 ${ }^{20-22)}$. 전뇌방사선치료 시 일반적으로 총 $30 \mathrm{~Gy}$ 의 방 사선을 10 회에 걸쳐서 조사하며 추가적으로 뇌정위방사선수술기법을 사용하여 추가적인 방사선을 고려하기도 한다 ${ }^{23,24)}$. 전뇌방사선치 료는 이차원방사선치료기법을 방사선수술은 뇌정위방사선수술기법을 적용한다(Figure 4).

(B)

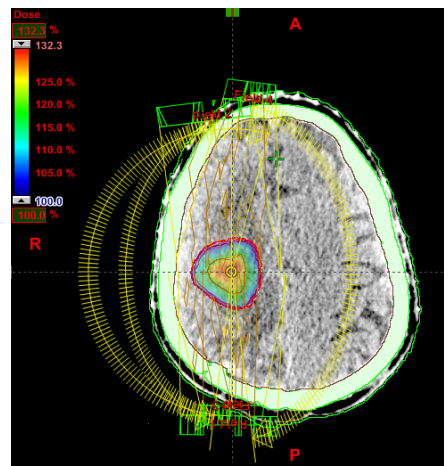

Figure 4. Radiation therapy for brain metastasis (A) whole brain radiation therapy technique (B) stereotactic radiosurgery technique

2) 다발성 뇌전이가 있는 경우(multiple brain metastses)

다발성 뇌전이가 있는 경우 스테로이드 단 독 사용에 비하여 전뇌방사선치료를 시행하는 것이 증상호전 뿐 아니라 중앙생존값을 향상 시키는 알려져 있다. 또한 전이병변의 수가 4 개 이내이면서 병변의 크기가 $4 \mathrm{~cm}$ 이내인 경 우 전뇌 방사선치료를 시행하며 환자의 활동 지수 및 예후 등 인자들을 고려하여 방사선수 술을 시행 할 수 있다 ${ }^{25,26)}$.

\section{4. 골전이(bone metastasis)}

\subsection{1. 배경}

골전이는 암성 통증의 대표적 원인이닥. 이러한 골전이의 대표적인 원발암으로 전립선
암, 유방암, 갑상선압, 폐암, 그리고 신장암을 들 수 있다 ${ }^{6,27,28)}$. 골전이를 동반환 환자들의 예후는 대개, 원발암 종류에 의해 결정되어 원 발암들 중 유방암 그리고 전립선암인 경우 평균 생존기간이 가장 긴 편으로 반면, 폐암인 경우 생존기간이 가장 짧은 것으로 알려져 있다 ${ }^{29)}$.

\subsection{2. 진단}

문진 및 진찰을 시행하며 통증양상, 골절위 험도, 체중부하 골(weight bearing bone) 전이 여부를 판정하고 이를 위하여 단순 촬영(plain X-ray film), 그리고 골스캔(bone scan)을 시행 하여야 한다. 골전이 주위에 종괴가 만져지거 나 신경학적 증상 등이 동반된 경우 컴퓨터 단 층촬영과 자기공명영상검사를 시행하여야 하 
며 원발암 진단이 불확실한 경우 조직검사를 고려하여야 한다.

\subsection{3. 치료}

골전이의 치료는 수술적치료, 항암약물요법, 호르몬치료, 그리고 방사선치료가 있다 ${ }^{29)}$. 골 전이가 동반된 환자에서 골절 혹은 척추압박 골절(spine compression fracture) 소견이 발견 되었거나 발생할 가능성이 높은 경우에는 수 술적 치료를 우선적으로 시행하여야 한다. 그 러나 골전이로 인한 통증 등 증상이 있을 경우 대부분 방사선치료를 시행하고 다발성으로 골 전이가 있으나 증상이 없는 경우 원발암에 대 한 항암화학요법을 시행하며 전립선암의 경우 호르몬치료를 사용한다. 방사선치료 시 통상적 으로 총 $30 \mathrm{~Gy}$ 방사선을 10 회에 나누어 조사 하며 활동지수가 불량하거나 기대여명이 3 개 월 미만인 경우 $8 \mathrm{~Gy}$ 를 1 회에 조사하거나 20 $\mathrm{Gy}$ 를 5회에 걸쳐 시행할 수 있으며 증상, 전 이부위, 전이범위, 그리고 골전이 주위 종괴유 무 등에 따라 다양하게 시행될 수 있다 ${ }^{30,}{ }^{31)}$.

\section{4. 고찰}

한국인 사망원인 1 위인 암은 국내 뿐 아니라 전세계 적으로 생존율향상에도 불구하고 전체 적 발생은 증가할 것으로 예측되고 있다 ${ }^{32)}$. 국 립암센터가 발표한 자료에 따르면 우리나라 국민의 평균수명인 81세까지 생존할 때 암에 걸릴 확률은 $36.2 \%$ 로 3 명 중 1 명은 암에 걸리 는 것으로 조사됐다. 암환자에서 암과 관련한 응급증상을 호소할 수 있고 첫 증상으로 암이 발견되기도 한다 ${ }^{33)}$. 이러한 응급상황에서 효과 적 진단과 적절한 치료는 환자의 증상완화 뿐 아니라 암치료에 있어서도 중요하다. 본 종설 에서는 암으로 인한 응급질환들 중 방사선치
료의 대표적 적응질환인 상대정맥증후군, 척수 압박증후군, 뇌전이 그리고 골전이에 대하여 살펴보았다.

상대정맥증후군은 1757 년 외과의사였던 윌 리엄 헌터에 의해 처음 기술이 되었고 악성종양 이 $90 \%$ 이상의 원인으로 알려져 있다 ${ }^{34,}{ }^{35)}$. 상 대정맥은 혈관이 얇고 상대적으로 혈관압력이 낮다. 반면, 주위에는 기관지, 흥골, 폐동맥, 그 리고 주기관지와 같은 단단한 구조물에 의하여 둘러싸여 압박에 민감하다. 상대정맥의 측부혈 류(collateral vessel syste)로 홀 (azygous), 유선 (mammary), 척추, 그리고 식도 혈관 등을 들 수 있으며 상대정맥 압박이 진행 될수록 측부혈류 의 확장이 유발되게 된다. 악성암 이외에 상대 정맥 증후군을 일으킬 수 있는 원인들로 카테터 에 의한 혈전증(catheter induced thrombosis), 만 성 종격동염(chronic mediasinitis), 복장뼈뒤 갑 상샘종(retrosternal goiter) 및 만성심부전증 (chronic heart failure)을 들 수 있다. 종양과 관 련한 상대정맥증후군 환자들의 평균여명은 원 발암의 종류에 따라 차이가 있으나 일반적으로 약 6 9개월로 알려져 있다. 진단적 검사방법을 자세히 살펴보면 객담검사, 조직검사, 기관지내 시경, 종격동경, 비디오흉강경수술 그리고 초음 파기관지 내시경(endobronchial ultrasound, EBUS) 등을 들 수 있다. 일반적으로 방사선치 료에 대한 전체적인 반응률은 약 $60 \%$ 정도로 보 고되며 치료 시작 후 수일 이내에 환자들 중 약 $85 \sim 90 \%$ 에서 증상완화를 보이는 것으로 알려져 있다 ${ }^{10,11)}$. 폐암으로 상대정맥증후군이 발생한 환자들 46명을 대상으로 항암약물요법과 방사 선치료를 시행했던 연구에서 비소세포암 환자 들 중 약 $60 \%$ 그리고 소세포암 환자들 중 약 $77 \%$ 에서 증상완화를 보고한 바 있다 ${ }^{5)}$.

척수압박증후군 환자들을 대상으로 다양한 방사선량이 시행한 연구에서는 $8 \mathrm{~Gy}$ 방사선을 1 회에 조사한 그룹, $20 \mathrm{~Gy}$ 방사선을 5 회에 나 
누어 조사한 그룹, $30 \mathrm{~Gy}$ 방사선을 10 회 나누 어 조사한 그룹, $37.5 \mathrm{~Gy}$ 방사선을 15 회에 나 누어 조사한 그룹, 그리고 $40 \mathrm{~Gy}$ 방사선을 20 회에 나누어 조사한 그룹을 치료 후 각 그룹 간 치료성적을 비교·분석하였는데, 그룹간 비 슷한 보행률(63-74\%) 그리고 운동기능향상 (26-31\%)로 보고한 바 있다 ${ }^{36)}$. 그러나 짧은 기 간 내 치료가 끝난 그룹에서 치료부위 재발이 높아 본 연구에서는 항암약물요법에 반응이 없고 진행이 뚜렷한 경우 $8 \mathrm{~Gy}$ 방사선을 1 회 에 조사하거나 $4 \mathrm{~Gy}$ 방사선을 5 회에 나누어 시행할 수 있으나 표준적으로는 $30 \mathrm{~Gy}$ 방사선 을 10 회에 나누어 시행하여야 한다고 권유하 였다. 척수압박증후군을 유발하는 원인으로 매 우 드물지만 척수 수질내 전이(intramedullary spinal cord metastasis)와 연수막암종증 (leptomeningeal seeding)을 들 수 있다 ${ }^{37,38)}$.

뇌전이암 환자의 예후를 결정하는 인자들로 환자의 활동지수, 원발질환의 조절여부, 진단 당시 환자나이(65세 기준), 그리고 뇌 이외에 전이여부를 들 수 있다 ${ }^{23)}$. 각 인자들의 평가점 수에 따른 합에 의해 class I, II 그리고 III로 분 류하였을 때 class I인 경우 평균생존율은 7.2 개 월, II인 경우 4.2개월, 그리고 III인 경우 2.3 개 월로 보고 되었달. 일반적으로 뇌전이에 대한 치료방법으로 스테로이드, 수술, 방사선치료가 있다. 새로 진단된 뇌전이암 환자에서 우선적 으로 스테로이드 $(4 \mathrm{mg}$ dexamethasone 6 시간 간 격으로 투여하며 초기용량은 $10 \mathrm{mg}$ 을 투여하고 이후 수술적 절제 또는 방사선치료 시행 여부 를 결정하여야 한다. 이러한 치료법들 중 방사 선치료의 경우, 대표적으로 전뇌방사선치료 (whole brain radiation therapy, WBRT)와 방사 선수술(stereotactic radiosurgery, SRS)로 나눌 수 있다. 뇌전이 진단 후 어떠한 치료도 시행하 지 않았을 경우, 평균 생존기간은 약 1달로 알 려져 있다. 1950년대 중반에 뇌전이암 치료에
전뇌방사선치료법으로 평균 생존기간을 1 개월 에서 3 6개월까지 향상시킬 수 있음을 보고 ${ }^{39-41)}$ 한 이후로 1980 년대에는 전뇌방사선치료가 뇌전이암의 표준방사선치료 방법으로 자리잡 게 되었다. 이후 새로운 방사선치료기법과 더 불어 영상학적 기술의 발전으로 현재, 방사선 수술 등 다양한 치료방법이 시행되게 되었다. 방사선치료방법은 뇌전이의 개수가 얼마인가 에 따라 정해지며 일반적으로 다발성인 경우 전뇌방사선치료를 단독 혹은 뇌전이 개수가 적 은 경우에는 방사선수술을 시도하게 된다. 또 한 뇌전이 종양의 크기도 치료방법 결정에 중 요한 요인으로 일반적으로 $4 \mathrm{~cm}$ 보다 작은 경 우에는 방사선수술을 시도할 수 있으며 환자의 활동지수, 뇌 이외 부위의 조절여부(controlled extra-cranial disease) 등도 방사선치료방법을 결정하는 중요한 인자들이다 ${ }^{24,42,43)}$. 뇌전이암 환자에서 시행되는 방사선치료 방법결정은 크 게 다음과 같이 2 가지 경우로 분류할 수 있다.

현재, 종양응급 상황에서 방사선치료가 필요 한 경우 전통적 방사선치료기법에서부터 최신 방사선치료기법까지 다양한 치료방법이 적용 될 수 있다. 이러한 치료 기법들을 살펴보면 우선 이차원 방사선치료기법(2D-RT)을 들 수 있다. 이는 전통적으로 시행되어 왔던 방사선 치료 기법으로 삼차원 입체조형방사선치료 기 법과 달리 계획용 컴퓨터 단층촬영 영상을 촬 영하지 않고 모의설계실에서 치료 부위에 대한 2차원 영상을 획득하고 이를 바탕으로 보호할 수 있는 정상장기에 대하여 차폐물(block) 혹은 다엽콜리메이터(multileaf collimator, MLC)를 이용한 차폐를 시행, 동시에 치료부위를 정하 며 방사선량계산 후 방사선치료를 시행하게 된 다. 상대정맥증후군 혹은 척수압박증후군과 같 이 응급질환이 발생한 경우, 삼차원 입체조형 방사선치료 시 시행하는 컴퓨터 단층촬영을 생 략하고 이차원 방사선치료기법을 진행하며 어 
느 정도 증상완화가 이루어진 시점에서 정상조 직 보호를 위해 삼차원 입체조형방사선치료 기 법으로 변경 후 치료를 진행할 수 있다. 반면, 일반적으로 종양응급 상황에서 사용하는 방사 선치료기법인 삼차원입체조형방사선치료기법 (3D-CRT)은 계획용 컴퓨터단층촬영 영상을 바 탕으로 종양과 주위 정상 장기를 3 차원적으로 구성하여 가능한 정상 장기를 피하면서 다양한

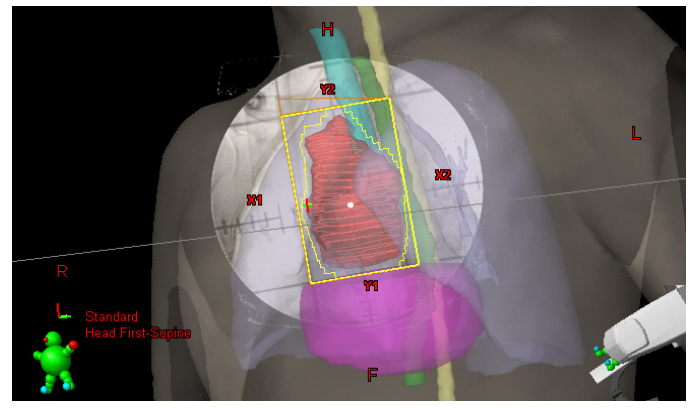

방향을 사용하여 종양의 모양에 따라 방사선량 을 전달하고자 한 설계방법이다 ${ }^{44)}$. 특히, 동일 평면상의 방사선뿐만 아니라 그 외의 다양한 방향에서 방사선을 전달할 수 있어, 기존의 이 차원 방사선치료기법에 비해 정상 조직을 보호 하면서 종양에 더 많은 방사선을 조사할 수 있 다(Figure 5).

Figure 5. Three dimensional radiation therapy planning by using multiple beams while avoiding the spinal cord, lung, and heart which can make treatment possible with less dose of radiation exposed to the normal tissues.

최신 방사선치료기법에 속하는 세기조절 방사 선치료(intensity modulated radiation thrapy, IMRT)는 단일 방사선 조사 범위를 더욱 작은 범 위로 나눠 각각의 범위의 방사선 세기를 다양한 크기로 조절함으로 정상 장기는 방사선량을 최 소화하면서 종양에 많은 방사선량을 주고자 하 는 치료법으로 3 차원 입체조형 방사선치료법 보 다 더 정밀하고 효율적으로 방사선을 조사할 수 있다. 삼차원 입체조형 방사선치료법과 달리 동 시에 종양에 다양한 분할선량(fraction size)을 조 사할 수 있는데 이를 동시통합추가방사선조사 (simultaneous integrated boost, SIB)기법이라고 한다 ${ }^{45}$. 두경부암에서 구강건조증(xerostomia) 방 지에 탁월한 효과가 보고되었고 전립선암에서 는 방광과 직장을 보다 효과적으로 보호할 수 있다(Figure 7). 이러한 세기조절 방사선치료 기 법에 바탕으로 더욱 발전된 방사선치료 기법으 로 세기조절방사선치료에 비하여 치료시간이
짧은 등 체적조절회전방사선치료(volumetric modulated radiation therapy, VMAT)가 있으며 이러한 최신 방사선치료기법을 사용하여 뇌전 이 혹은 척수압박증후군 등 종양응급상황에서 치료가 시행되고 있담). 통상적인 방사선치료 가 수 주에 걸쳐서 치료가 진행되는데 비하여 방사선수술기법은 고선량의 방사선을 일회 혹 은 수회에 걸쳐 짧은 기간에 조사하는 방법으로 외과적 수술을 하는 것은 아니나 고도의 정밀도 와 정확성을 바탕으로 병변 부위에 고선량 방사 선을 조사함으로써 외과적 수술결과와 비슷한 치료성적을 보고하고 있다. 이러한 방사선수술 기법은 고도의 정밀도를 바탕으로 시행되어 정 위적 방사선수술(SRS)라고도 하며 주로 뇌종양 에 시행되어 오던 것이 근래에는 뇌종양 이외에 도 폐(원발성 혹은 전이성암), 간(원발성 혹은 전이성암), 그리고 척추(원발성 혹은 전이성암) 에서도 체부정위방사선수술(SBRT) 이 시행되고 
있다. 일반적으로 4 5회 정도의 방사선을 조사 하고 수술에 준하는 치료 성적을 보이며 외래로 치료가 가능하다는 장점이 있다. 정위적 방사선 수술 시 비침습적(noninvasive)이면서 정밀한 치 료가 가능하도록 보조기구를 사용한다(Figure 6). 전이가 있는 환자의 경우 낮은 생존율로 인 하여 방사선치료 방법에 있어서도 정상조직손 상에 대한 고려가 적은 방사선치료 기법을 사용 하였었으나 근래 연구결과에 따르면 전이가 있 어도 수술적 절제를 하였을 경우 장기 생존율이 보고되고 있어 수술로 절제가 어렵거나 고령 등 의 이유로 수술을 시행할 수 없는 환자에서 방
사선수술기법을 이용한 치료가 활발히 시행되 고 있다 ${ }^{47)}$. 이러한 정밀한 치료를 가능하게 하 는 중요한 치료기법인 영상유도 방사선치료기 법(image guided radiation therapy, IGRT)은 방 사선 치료계획 당시 획득한 영상과 치료 직전에 획득한 영상을 비교함으로써 그 차이를 교정하 여 치료의 정확성을 높임으로써 정밀한 치료를 가능하도록 하는 치료방법으로 치료기에 혹은 치료실에 설치된 엑스선 투시장비 (exac trac 혹 은 cone beam CT)와 같은 영상획득 장치를 이 용함으로써 영상유도 방사선치료를 시행할 수 있다(Figure 7).

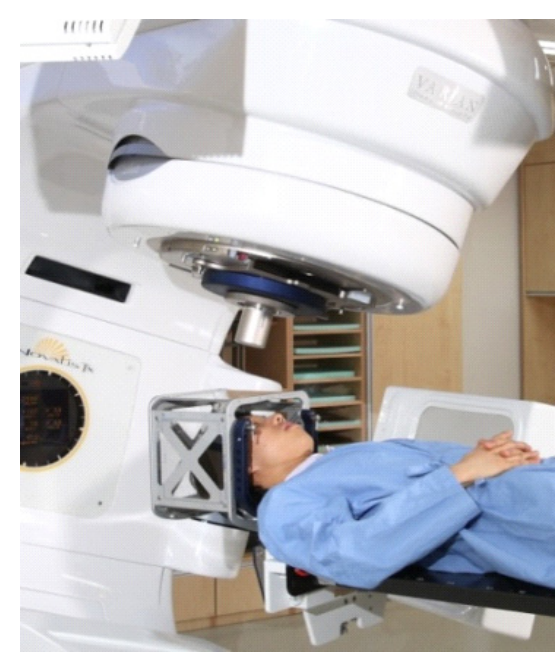

Figure 6. Applicators for stereotactic radiosurgery
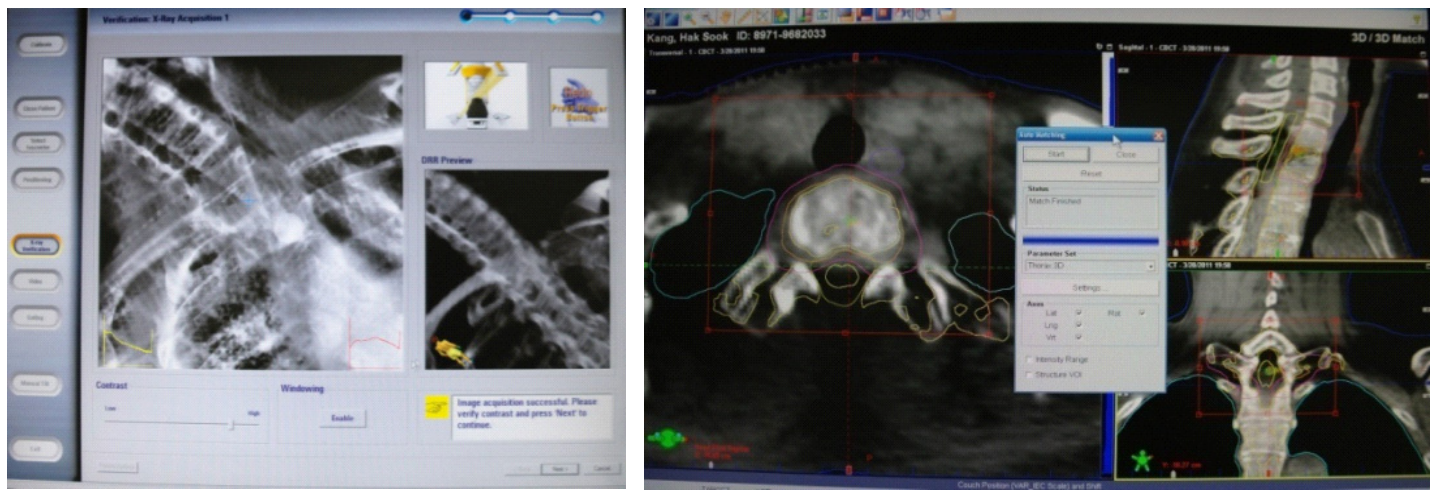

Figure 7. Image guided radiation therapy: spine metastasis

환자의 움직임을 고려한 방사선치료기법을 적용하는 경우는 대표적으로 폐나 간에 발생 한 종양이 해당되는데 호흡으로 인해 종양이
움직이는 폐암 혹은 간암의 경우에 통상적인 방사선치료 기법을 사용하였을 때 이러한 움 직임을 고려할 경우 움직임이 없을 경우에 비 
하여 치료범위가 커지게 되며 이로 인하여 정 상 폐 혹은 간에 부작용 발생 가능성이 증가하 게 된다. 이 경우 호흡에 따른 종양의 위치를 분석하여 특정 호흡주기에 도달하였을 때 방 사선을 조사하면 방사선치료 범위를 줄일 수 있어 종양에는 충분한 방사선량을 조사하면서
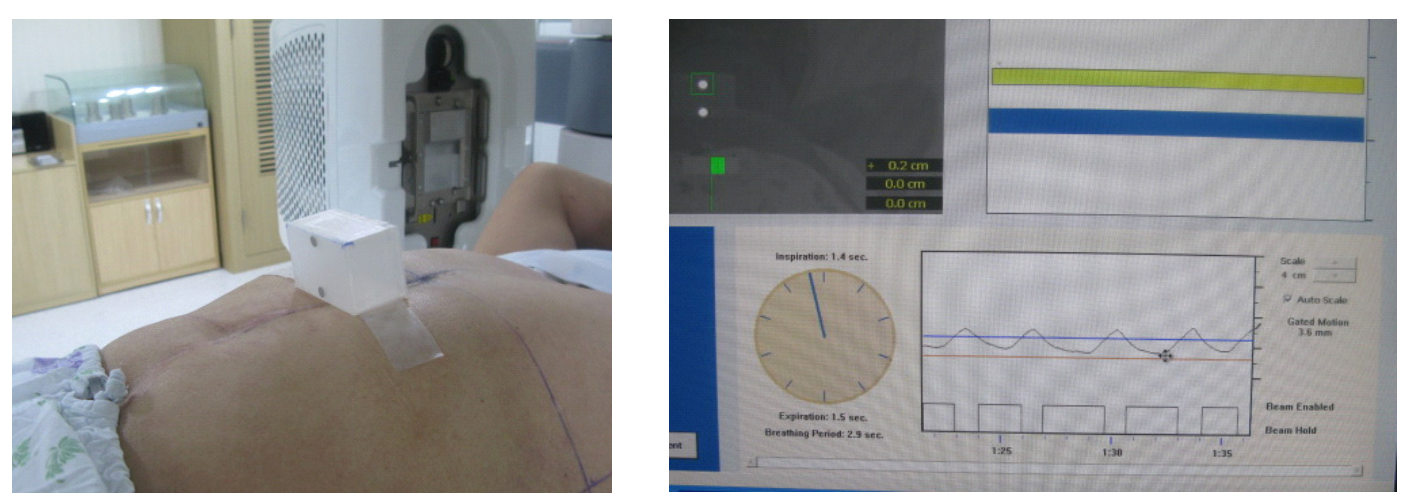

Figure 8. Respiratory gated radiation therapy: metastatic lung cancer

\section{5. 결론}

본 연구에서는 방사선치료가 시행되는 대표 적 종양응급 질환들과 현재 시행되고 있는 통 상적 그리고 최신 방사선치료기법들에 대하여 문헌고찰을 바탕으로 살펴보고자 하였다. 암환 자가 증가함에 따라 종양응급 상황 또한 증가 할 것으로 예측된다. 이러한 종양응급 상황에 서 방사선치료의 역할은 환자의 생명 뿐 아니 라 삶의 질을 향상시킨다는 점에서 매우 중요 하다. 나아가 정상장기의 방사선량은 최소화하 면서 종양에는 더 많은 방사선량 조사가 가능 한 세기조절 방사선치료 및 방사선수술 등 방 사선치료기법의 빠른 발전으로 부작용 감소, 종양의 국소조절을 통한 증상완화 뿐 아니라 일부 환자에서는 생존율 향상을 통한 근치적 치료까지 기대할 수 있게 되었다. 결론적으로 종양응급 상황에서 방사선치료는 환자의 증상 조절 뿐 아니라 일부 환자에서 생존율 향상에 있어 필수적인 치료방법으로 향후, 그 역할은 점점 더 증가할 것이다.
주위 정상장기를 보호할 수 있는데, 이러한 치 료방법을 호흡연동방사선치료기법(respiratory gated radiation therapy)이라고 한다(Figure 8). 
6. Kvale PA, Selecky PA, Prakash UB. Palliative care in lung cancer: ACCP evidence-based clinical practice guidelines (2nd edition). Chest 2007; 132:368S-403S.

7. Ostler PJ, Clarke DP, Watkinson AF, et al. Superior vena cava obstruction: a modern management strategy. Clin Oncol (R Coll Radiol) 1997;9:83-89.

8. Kaplan AP, Greaves MW. Angioedema. J Am Acad Dermatol 2005;53:373-388;quiz 389-392

9. Wan JF, Bezjak A. Superior vena cava syndrome. Emerg Med Clin North Am 2009;27:243-255.

10. Slawson RG, Scott RM. Radiation therapy in bronchogenic carcinoma. Radiology 1979; 132:175-176.

11. Davenport D, Ferree C, Blake D, et al. Response of superior vena cava syndrome to radiation therapy.Cancer 1976;38:1577-1580.

12. Halfdanarson TR, Hogan WJ, Moynihan TJ. Oncologic emergencies: diagnosis and treatment. Mayo Clin Proc 2006;81:835-848.

13. Schiff D. Spinal cord compression. Neurol Clin 2003;21:67-86, viii.

14. Cole JS, Patchell RA. Metastatic epidural spinal cord compression. Lancet Neurol 2008;7:459-466.

15. Patchell RA, Tibbs PA, Regine WF, et al. Direct decompressive surgical resection in the treatment of spinal cord compression caused by metastatic cancer: a randomised trial. Lancet 2005;366:643-648.

16. Gavrilovic IT, Posner JB. Brain metastases: epidemiology and pathophysiology. J Neurooncol 2005;75:5-14.

17. Barnholtz-Sloan JS, Sloan AE, Davis FG, et al. Incidence proportions of brain metastases in patients diagnosed (1973 to 2001) in the Metropolitan Detroit Cancer Surveillance System. J Clin Oncol 2004;22:2865-2872.

18. SchoutenLJ, Rutten J, Huveneers HA, et al. Incidence of brain metastases in a cohort of patients with carcinoma of the breast, colon, kidney, and lung and melanoma. Cancer 2002;94:2698-2705.

19. Delattre JY, Krol G, Thaler HT, et al. Distribution of brain metastases. Arch Neurol 1988;45:741-744.

20. Tsao MN, Lloyd NS, Wong RK, et al. Radiotherapeutic management of brain metastases: a systematic review and meta-analysis. Cancer Treat Rev 2005;31:2 56-273.

21. Patchell RA, Tibbs PA, Regine WF, et al. Postoperative radiotherapy in the treatment of single metastases to the brain: a randomized trial. JAMA 1998;280:14851489.

22. Gaspar LE, Mehta MP, Patchell RA, et al. The role of whole brain radiation therapy in the management of newly diagnosed brain metastases: a systematic review and evidence-based clinical practice guideline. J Neurooncol 2010;96:17-32.

23. Gaspar L, Scott C, Rotman M, et al. Recursive partitioning analysis (RPA) of prognostic factors in three Radiation Therapy Oncology Group (RTOG) brain metastases trials. Int J Radiat Oncol Biol Phys 1997;37:745-751.

24. Mintz A, Perry J, Spithoff $\mathrm{K}$, et al. Management of single brain metastasis: a practice guideline. Curr Oncol 2007;14: 131-143. 
25. Mehta MP, Tsao MN, Whelan TJ, et al. The American Society for Therapeutic Radiology and Oncology (ASTRO) evidence-based review of the role of radiosurgery for brain metastases. Int J Radiat Oncol Biol Phys 2005;63:37-46.

26. Linskey ME, Andrews DW, Asher AL, et al. The role of stereotactic radiosurgery in the management ofpatients with newly diagnosed brain metastases: a systematic review and evidence-based clinical practice guideline. J Neurooncol 2010;96:45-68.

27. Coleman RE. Clinical features of metastatic bone disease and risk of skeletal morbidity. Clin Cancer Res 2006;12:6243s-6249s.

28. Nielsen OS, Munro AJ, Tannock IF. Bone metastases: pathophysiology and management policy. J Clin Oncol 1991;9: 509-524.

29. Lutz S, Lo SS, Chow E, et al. Radiotherapy for metastatic bone disease: current standards and future prospectus. Expert Rev Anticancer Ther 2010;10:683-695.

30. Wu JS, Wong RK, Lloyd NS, et al. Radiotherapy fractionation for the palliation of uncomplicated painful bone metastases an evidence-based practice guideline. BMC Cancer 2004;4:71.

31. Roos DE, Turner SL, O'Brien PC, et al. Randomized trial of 8 Gy in 1 versus $20 \mathrm{~Gy}$ in 5 fractions of radiotherapy for neuropathic pain due to bone metastases (Trans-Tasman Radiation Oncology Group, TROG 96.05). Radiother Oncol 2005;75:54-63.

32. Mariotto AB, Yabroff KR, Shao Y, et al. Projections of the cost of cancer care in the United States: 2010-2020. J Natl Cancer Inst 2011;103:117-128.
33. Schiff D, O'Neill BP, Suman VJ. Spinal .epidural metastasis as the initial manifestation of malignancy: clinical features and diagnostic approach. Neurology 1997;49: $452-456$

34. Stehbens WE. History of aneurysms. Med Hist 1958;2:274-280.

35. Wilson LD, Detterbeck FC, Yahalom J. Clinical practice. Superior vena cava syndrome with malignant causes. $\mathrm{N}$ Engl J Med 2007;356:1862-1869.

36. Rades D, Stalpers LJ, Veninga $\mathrm{T}$, et al. Evaluation of five radiation schedules and prognostic factors for metastatic spinal cord compression. J Clin Oncol 2005;23:33663375.

37. Kalayci M, Cagavi F, Gul S, et al. Intramedullary spinal cord metastases: diagnosis and treatment - an illustrated review. Acta Neurochir (Wien) 2004;146: 1347-1354.

38. Boogerd W, Hart AA, van der Sande JJ, et al. Meningeal carcinomatosis in breast cancer. Prognostic factors and influence of treatment. Cancer 1991;67:1685-1695.

39. Markesbery WR, Brooks WH, Gupta GD, et al. Treatment for patients with cerebral metastases. Arch Neurol 1978;35:754-756.

40. Egawa S, Tukiyama I, Akine $\mathrm{Y}$, et al. Radiotherapy of brain metastases. Int $\mathrm{J}$ Radiat Oncol Biol Phys 1986;12:1621-1625.

41. Horton J, Baxter DH, Olson KB. The management of metastases to the brain by irradiation and corticosteroids. Am J Roentgenol Radium Ther Nucl Med 1971;111:334-336.

42. Aoyama H, Shirato H, Tago $M$, et al. 
Stereotactic radiosurgery plus whole-brain radiation therapy vs stereotactic radiosurgery alone for treatment of brain metastases: a randomized controlled trial. JAMA 2006;295:2483-2491.

43. Andrews DW, Scott CB, Sperduto PW, et al. Whole brain radiation therapy with or without stereotactic radiosurgery boost for patients with one to three brain metastases: phase III results of the RTOG 9508 randomised trial. Lancet 2004;363:16651672.

44. Goitein M, Abrams M, Rowell D, et al. Multi-dimensional treatment planning: II. Beam's eye-view, back projection, and projection through $\mathrm{CT}$ sections. Int $\mathrm{J}$ Radiat Oncol Biol Phys 1983;9:789-797.

45. Mohan R, Wu Q, Wang X, et al. Intensity modulation optimization, lateral transport of radiation, and margins. Med Phys 1996; 23:2011-2021.

46. Lee $\mathrm{SH}$, Lee $\mathrm{KC}$, Choi J, et al. Clinical application of RapidArc volumetric modulated arc therapy as a component in whole brain radiation therapy for poor prognostic, four or more multiple brain metastases. Radiat Oncol J 2012;30:53-61.

47. Fong Y, Fortner J, Sun RL,et al. Clinical score for predicting recurrence after hepatic resection for metastatic colorectal cancer: analysis of 1001 consecutive cases. Ann Surg 1999;230: 309-318; discussion 318-321. 